\title{
Analisis Kualitas Pelayanan Program Jaminan Kesehatan Nasional di Ruang Rawat Inap Rumah Sakit X Kabupaten Kerinci
}

Widiya Wati ${ }^{1}$, Rizanda Machmud², Yurniwati ${ }^{3}$

\begin{abstract}
Abstrak
Rumah Sakit X Kabupaten Kerinci mulai bekerja sama dengan BPJS Kesehatan sejak tahun 2014, dalam penyelenggaraannya mendapat berbagai keluhaan dan ketidakpuasan pasien dengan pelayanan yang diberikan disebabkan masih ada beberapa petugas rumah sakit yang kurang ramah dalam melayani pasien serta fasilitas ruangan yang kurang memadai. Tujuan penelitian ini adalah menganalisis kualitas pelayanan kesehatan pada pasien jaminan kesehatan nasional diruang rawat inap. Jenis penelitian yang digunakan adalah studi kualitatif dengan melakukan wawancara mendalam (Indepth Interview), Focus Group Discussion (FGD) dan telaah dokumen. Informan dalam pelitian ini berjumlah 13 orang dari Rumah Sakit, 1 orang dari BPJS Kesehatan dan 6 orang dari pasien rumah sakit. Hasil penelitian untuk komponen input, kebijakan belum tersosialisasi dengan optimal, SDM masih kurang, serta sarana prasarana diruang rawat inap masih kurang. Komponen proses, dimensi mutu tangibility terdapat kekurangan pada fasilitas diruang rawat inap seperti tidak adanya tirai pembatas, pendingin ruangan serta ruangan penuh sesak, dimensi mutu reability, responsiveness, assurance,dan emphaty mendapat penilaian yang baik dan pada proses pengajuan klaim RS selalu terlambat setiap bulannya karena RS belum menggunakan SIMRS. Komponen output dimensi mutu Tangibility responden belum merasa puas, dimensi mutu reability, responsiveness, assurance, emphaty sudah bisa menjawab kebutuhan responden.
\end{abstract}

Kata kunci: kualitas pelayanan, JKN, kepuasan pasien

\begin{abstract}
X Hospital, Kerinci Regency has began working with BPJS Kesehatan since 2014, in the implementation of receiving various complaints and dissatisfaction of patients with services provided because there are still some hospital staff who are less friendly in serving patients and inadequate room facilities. The objective of this study was to analyze the quality of health services in patients with national health insurance in the inpatient room. The type of research used is a qualitative study by conducting in-depth interviews (Indepth Interview), Focus Group Discussion (FGD) and Document Studies. The informants in this report were thirteen persons from hospital employee, one person from BPJS Kesehatan and six persons from hospital patients. The results of research is for the input component, policies have not been socialized optimally, human resources and infrastructure facilities in the inpatient room are still lacking. Process components, tangibility quality dimensions are lacking in facilities in the inpatient room such as the absence of limiting curtains, overcrowded air conditioners and rooms, quality reability, responsiveness, assurance and empathy dimensions get good ratings from respondents and always late in filing hospital claims every month because the hospital has not used SIMRS. Output component of the Tangibility quality dimension of the respondent has not been satisfied, the dimensions of quality reability, responsiveness, assurance, empathy have been able to answer the respondent's needs.
\end{abstract}

Keywords:Quality Service, JKN,Patient Satisfaction 
Affiliasi penulis: 1. Prodi Pasca Sarjana Kesehatan Masyarakat Universitas Andalas Padang, 2. Fakultas IImu Keperawatan Universitas Andalas Padang, 3. Departemen Akuntansi, Fakultas Ekonomi Universitas Andalas Padang

Korespondensi: Rizanda Machmud, Email:

rizanda_machmud@yahoo.ac.id Telp: 082132809619

\section{PENDAHULUAN}

Pembukaan Undang-Undang Dasar Negara Republik Indonesia Tahun 1945 diamanatkan bahwa tujuan negara adalah untuk meningkatkan kesejahteraan rakyat, kesejahteraan tersebut harus dapat dinikmati secara berkelanjutan, adil, dan merata menjangkau seluruh rakyat. Tujuan tersebut semakin dipertegas yaitu dengan mengembangkan sistem jaminan sosial di Indonesia. Sistem jaminan sosial nasional merupakan program negara yang bertujuan memberikan kepastian jaminan yang lebih menyeluruh dan terpadu bagi setiap masyarakat Indonesia agar dapat hidup sehat, produktif, dan sejahtera. Undang-Undang No. 24 Tahun 2011 juga menetapkan, jaminan sosial nasional akan diselenggarakan oleh BPJS, yang terdiri dari BPJS Ketenagakerjaan dan BPJS Kesehatan. ${ }^{1}$

BPJS Kesehatan dalam Undang-Undang No. 24 Tahun 2011 bersifat wajib bagi seluruh rakyat Indonesia, ${ }^{1}$ namun dalam implementasi program BPJS Kesehatan belum semua penduduk menjadi peserta BPJS dan menurut data BPJS Kesehatan Maret 2016 sebanyak 163.327 .183 orang peserta atau sekitar $63 \%$ dari rakyat Indonesia yang terdaftar, hal ini berarti masih ada $37 \%$ rakyat Indonesia yang belum mendapatkan jaminan kesehatan (Badan Penyelenggaraan Jaminan Sosial Tahun 2016), begitu juga dengan kepesertaan BPJS Kesehatan Kabupaten Kerinci dari jumlah penduduk 253.258 jiwa yang terdaftar keanggotaan sebanyak 159.045 jiwa (62.8\%), sehingga masih ada 94.212 jiwa yang belom terdaftar atau sekitar $37.2 \%{ }^{2}$

Menurut Kabid Keperawatan di Rumah Sakit X Kabupaten Kerinci, banyaknya masyarakat yang belum mendaftar menjadi peserta BPJS tersebut menimbulkan masalah dalam pelayanan kesehatan. Masyarakat daerah kerinci yang tidak memiliki kartu JKN khususnya dari kalangan masyarakat yang kurang mampu akan sulit mendapatkan pelayanan kesehatan yang murah, kesulitan biaya tersebut membuat mereka tidak mau berobat kalau penyakitnya belum parah. Akibatnya banyak masyarakat yang sakit terpaksa berobat dan dirawat dengan biaya yang tinggi.

Hasil survei pendahuluan yang telah peneliti lakukan terhadap 20 responden pasien BPJS Kesehatan di Rumah Sakit X Kabupaten Kerinci diketahui 13 dari 20 responden mengatakan kurang puas dengan pelayanan yang diberikan disebabkan masih ada beberapa petugas rumah sakit yang kurang ramah dalam melayani pasien serta fasilitas ruangan yang kurang memadai.

Pada pengajuan klaim di Rumah Sakit $X$ Kabupaten Kerinci terdapat masalah yang penulis temui yaitu terlambatnya pengajuan klaim oleh rumah sakit ke BPJS Kesehatan. Dari awal berjalannya program BPJS di Rumah Sakit X Kabupaten Kerinci sampai bulan maret 2016 klaim selalu terlambat diajukan yaitu lewat dari tanggal 10 bulan berikutnya (laporan bagian mobilisasi dana) hal ini berdampak langsung bagi rumah sakit, mulai dari menumpuknya berkas klaim yang harus diverifikasi sampai masalah keuangan (terlambat pembayaran insentif staf). Hal ini sedikit banyak berpengaruh terhadap pelayanan kesehatan di Rumah Sakit X Kabupaten Kerinci

Penelitian ini bertujuan untuk mengetahui analisis kualitas pelayanan program Jaminan Kesehatan Nasional di Ruang Rawat Inap Rumah Sakit X Kabupaten Kerinci Tahun 2018.

\section{METODE}

Penelitian ini menggunakan pendekatan deskriptif dengan desain penelitian kualitatif yang bertujuan untuk mendapatkan gambaran mendalam tentang pelaksanaan implementasi program Jaminan Kesehatan Nasional (JKN) diruang rawat inap Rumah Sakit $X$ Kabupaten Kerinci. $^{3}$ Penelitian ini dilakukan pada bulan Mei 2017 sampai Maret 2018.

Pemilihan informan dalam penelitian ini menggunakan teknik purposive sampling yang dianggap memahami, mengetahui masalah pelayanan pada program jaminan kesehatan nasional dan pengambilan sampel harus benar-benar mencerminkan keadaan populasi itu sendiri. ${ }^{4}$ Informan dalam penelitian ini adalah direktur, wakil direktur bidang pelayanan medis, kepala instalasi rawat inap, 
kepala ruangan rawat inap, pegawai BPJS dirumah sakit, kepala bidang mobilisasi dana, petugas entry data, petugas audit verifikator, perawat ruang rawat inap 6 orang dan pasien JKN 6 orang.

Data primer didapatkan melalui wawancara, Focus Group Discussion (FGD) dan observasi untuk mengumpulkan informasi mengenai kualitas pelayanan pada program jaminan kesehatan nasional. Data sekunder didapat melalui telaah dokumen yang berhubungan dengan aktifitas pelayanan pada program jaminan kesehatan nasional, seperti laporan kerja sama, laporan jumlah tenaga kesehatan, laporan jumlah kunjungan, data sarana prasarana dan dokumen pendukung lainnya.

\section{HASIL}

\section{Kompunen Input}

- Kebijakan

Hasil wawancara mendalam, FGD dan telaah dokumen ditemukan bahwa dalam implementasi jaminan kesehatan nasional di Rumah Sakit $X$ Kabupaten Kerinci berpedoman kepada kebijakan yang dikeluarkan oleh pemerintah pusat berupa Undang-Undang Dasar 1945, UU No 40 tahun 2004 tentang sistim jaminan kesehatan nasional, perjanjian kerja sama antara RS dengan BPJS, kebijakan ini telah disosialisasikan pada pegawai RS terbatas pada managemen puncak.

\section{SDM}

Hasil wawancara mendalam, FGD, telaah dokumen dan observasi ditemukan diruang rawat inap $\mathrm{K}$ dibutuhkan 33 orang, perawat yang ada 20 jadi selisihnya 13 orang perawat, ruang perawatan B dibutuhkan 17 orang, perwata yang ada 14 jadi selisihnya 3 orang, ruang I dibutuhkan 29 orang, perawat yang ada 18 jadi selisihnya 11 orang perawat dan ruang A dibutuhkan 21 orang, perawat yang ada 15 jadi selisihnya 6 orang perawat dan untuk tenaga pengajuan klaim di Rumah Sakit X Kabupaten Kerinci sudah cukup.

\section{Sarana Prasarana}

Hasil wawancara mendalam, FGD, telaah dokumen dan observasi ditemukan bahwa di Rumah Sakit X Kabupaten Kerinci masih adanya kekurangan pada sarana prasarana terutama pada ruang perawatan kelas II dan III. Peneliti menemukan masih banyaknya masalah seperti kurangnya kipas angin, ventilasi udara, dan tirai pembatas. Sarana prasarana pada proses pengajuan klaim masih kurang pada system SIMRS yang belum optimal sehingga harus di entry secara manual dan memakan waktu lama.

\section{Kompunen Proses}

\section{- Bukti Fisik}

Hasil FGD dan Observasi ditemukan fasilitas ruangan untuk mendukung peningkatan pelayanan Rumah Sakit X Kabupaten Kerinci masih ada yang perlu ditambah dan diperbaiki seperti tirai pembatas antara tempat tidur pasien tidak ada, ventilasi yang kurang dan kipas angin yang tidak bisa di pakai lagi.

\section{- Kehandalan}

Hasil FGD dan observasi ditemukan waktu tunggu untuk mendapatkan tempat tidur di Rumah Sakit X Kabupaten Kerinci membutuhkan waktu paling lambat 1 hari, hal ini sesuai dengan indikatator rumah sakit BOR sebesar $85 \%$, angka BOR menunjukkan tingkat pemamfaatan tempat tidur yang cukup tinggi dan tenaga kesehatan diruang rawat inap sudah cukup handal dalam menyelesaikan masalah yang dihadapi pasien, terlihat dari tidak ada kendala dalam melakukan tindakan perawatan.

\section{- Daya Tanggap}

Hasil FGD dan observasi ditemukan petugas kesehatan diruang rawat inap Rumah Sakit $X$ Kabupaten Kerinci cepat tanggap dalam membantu kebutuhan pasien dalam segala hal yang berkaitan dengan perawatan pasien. Informasi yang disampaikan petugas dapat dimengerti oleh pasien, petugas medis memberikan kesempatan paien bertanya dan perawat juga datang dengan cepat jika dibutuhkan tenaganya.

\section{- Jaminan}

Hasil FGD dan observasi ditemukan petugas kesehatan diruang rawat inap Rumah Sakit $X$ Kabupaten Kerinci melakukan tindakan perawatan yang baik dan sesuai prosedur yang ditetapkan. Setiap pertanyaan yang diajukan oleh pasien mengenai penyakitnya dijawab dengan sopan 


\section{- Kepedulian}

Hasil FGD dan observasi temukan tenaga kesehatan di ruang rawat inap Rumah Sakit $X$ Kabupaten Kerinci ramah dan peduli kepada pasien. Perawat dan dokter juga menanyakan kabar dari pasien, bagaimana kemajuan kesehatannya dan menyemangati pasien selama pasien tersebut dirawat di Rumah Sakit X Kabupaten Kerinci.

\section{- Pengajuan Klaim}

Sesuai dengan perjanjian kerjasama antara rumah sakit dengan BPJS Kesehatan maksimal pengajuan klaim dilakukan tanggal 10 bulan berikutnya, namun di Rumah Sakit $X$ Kabupaten Kerinci mengalami keterlambatan dalam pengajuan klaim, mulai dari bekerja sama dengan BPJS Kesehatan sampai tahun 2017. Rerata keterlambatannya sampai 3 bulan.

Hasil wawancara, observasi dan telaah dokumen ditemukan petunjuk teknis verifikasi sudah ada namun masih adanya keterlambatan pengajuan klaim dari rumah sakit hal ini disebabkan karena pihak managemen Rumah Sakit X Kabupaten Kerinci tidak melakukan supervisi secara berkala terhadap pelaksanaan program ini sehingga menyebabkan ketidaklengkapan pengisian rekam medis yang dikembalikan kebagian mobilisasi dana sebanyak 37\% ditahun 2017. Sehingga menyebabkan menumpuknya berkas klaim untuk di grouping dan koding. Dan pengentryan data secara manual karena rumah sakit belum menggunakan sistim SIMRS.

\section{Kompunen Output}

Mutu pelayanan kesehatan diruang rawat inap Rumah Sakit X Kabupaten Kerinci sudah cukup baik, terlihat dari dimensi mutu kehandalan, daya tanggap, jaminan dan kepedulian sudah memuaskan dan mampu menjawab kebutuhan responden, namun dari segi fasilitas ruangan yang masih mendapat beberapa keluhan responden.

\section{PEMBAHASAN}

\section{Kompunen Input}

\section{- Kebijakan}

Menurut Terry dalam Azwar menyatakan bahwa kebijakan adalah langkah yang bersifat luas, menyeluruh, lentur dan dinamik yang ditetapkan oleh para manager sebagai prioritas utama dalam upaya mencapai tujuan. ${ }^{5}$ Adapun kebijakan yang mengatur tentang program jaminan kesehatan nasional tertuang dalam Undang-Undang Nomor 40 Tahun 2004 tentang SJSN dengan bertujuan untuk memenuhi kebutuhan dasar kesehatan masyarakat yang layak yang diberikan kepada setiap orang yang telah membayar iuran atau iurannya dibayarkan pemerintah. $^{6}$

Berdasarkan hasil penelitian yang telah dilakukan, diketahui bahwa Rumah Sakit X Kabupaten Kerinci dalam melaksanakan pelayanan kesehatan pada pasien BPJS, berpedoman kepada kebijakan yang dikeluarkan oleh pemerintah pusat berupa Undang-Undang Dasar 1945, UU No 40 tahun 2004 tentang sistim jaminan kesehatan nasional, perjanjian kerja sama antara RS dengan BPJS, kebijakan ini telah disosialisasikan pada pegawai RS tapi hanya terbatas pada managemen puncak. Pegawai ruangan yang bersentuhan langsung dengan pasien BPJS setiap harinya tidak mengetahui adanya perubahaan kebijakan, hal tersebut akan menyebakan terjadinya kesalahan informasi yang disampaikan petugas ruangan kepada pasien. Sehingga perlu adanya sosialisasi ke pada pegawai diruangan perawatan, baik disosialisasikan secara langsung maupun dalam bentuk tertulis dan dibagikan kepada seluruh pegawai diruang rawat inap.

Penelitian yang dilakukan oleh Khariza (2015) tentang program jaminan kesehatan nasional, jika terjadi perubahan peraturan dan petunjuk yang terkait dengan pelaksanaan program jaminan kesehatan nasional di Rumah Sakit Jiwa Menur maka rapat formal menjadi salah satu cara yang efektif dalam penyampaian dan penyaluran informasi kepada seluruh bagian rumah sakit. ${ }^{7}$ Raymanel dalam penelitian Ernawati dan Azkha (2018) menyatakan penetapan kebijakan secara tertulis menjadi penting karena dalam pentahapannya prosesnya akan memiliki alur yang jelas dan pasti sehingga dapat menjadi dasar bagi seluruh staf dan dilakukan sosialisasi seluruh pegawai untuk dilaksanakan. ${ }^{8}$

Berdasarkan analisis peneliti tentang kebijakan jaminan kesehatan nasional, perlu adanya sosialisasi keseluruh pihak yang bertanggung jawab dan 
bersentuhan langsung dengan pasien BPJS dengan cara tertulis. Sosialisasi ini bukan hanya pada menajemen puncak saja dengan demikian jika terjadi perubahan-perubahan peraturan dan petunjuk yang terkait dengan pelaksanaan program Jaminan Kesehatan Nasional di Rumah Sakit X Kabupaten Kerinci seluruh petugas pelaksana akan dapat dengan mudah mendapatkan dan memperoleh infornamasi tersebut.

\section{- SDM}

Menurut Hasibuan (2016), Sumber daya manusia terdiri dari daya pikir dan daya fisik setiap manusia. Tegasnya kemampuan setiap manusia ditentukan oleh daya pikir dan daya fisiknya. Sumber daya manusia menjadi unsur pertama dan utama dari setiap aktivitas yang dilakukan. Peralatan yang andal/ canggih tanpaperan aktif SDM, tidak berarti apa-apa. ${ }^{9}$

Berdasarkan hasil penelitian yang telah dilakukan diketahui bahwa sumber daya manusia di Rumah Sakit $X$ Kabupaten Kerinci masih sangat kurang, hal tersebut terlihat dari perhitungan beban kerja yang peneliti lakukan pada setiap ranap, diruang rawat inap $\mathrm{K}$ dibutuhkan 33 orang, perawat yang ada 20 jadi selisihnya 13 orang perawat, ruang perawatan B dibutuhkan 17 orang, perwata yang ada 14 jadi selisihnya 3 orang, ruang I dibutuhkan 29 orang, perawat yang ada 18 jadi selisihnya 11 orang perawat dan ruang $A$ dibutuhkan 21 orang, perawat yang ada 15 jadi selisihnya 6 orang perawat. Hal ini menyebabkan beratnya beban kerja perawat dan kinerjanya menjadi kurang optimal.

Penelitian yang dilakukan oleh Khariza (2015), tentang studi deskriptif tentang faktor-faktor yang dapat mempengaruhi keberhasilan implementasi program jaminan kesehatan nasional dirumah sakit jiwa Menur Surabaya, dan didapatkan kuantitas SDM yang mencukupi sangat diperlukan untuk memaksimalkan pelayanan kesehatan yang ada. Jumlah penduduk yang banyak juga menuntut peningkatan jumlah SDM. ${ }^{7}$ Penelitian yang dilakukan oleh Saputra et al (2015), selain kuantitas, distribusi SDM pelaksana pelayanan kesehatan sangat penting, pada pelaksanaan JKN (Januari-Juni 2014), kuantitas dan distribusi SDM pelaksana pelayanan kesehatan masih mengalami kekurangan. ${ }^{10}$
Mendapatkan mutu pelayanan kesehatan yang baik dan kepuasan dalam pelayanan kesehatan perlu adanya kecukupan SDM, baik dari segi kualitas dan kuantitas SDM. Dan berdasarkan analisis peneliti perlu adanya penambahan tenaga kesehatan disetiap ruangan perawatan di Rumah Sakit X Kabupaten Kerinci sesuai dengan beban kerja di ruangan perawatan tersebut. Peningkatan kuantitas dan kualitas SDM juga sangat diperlukan karena Rumah Sakit $X$ Kabupaten Kerinci satu-satunya rumah sakit rujukan untuk pasien BPJS dikabupaten Kerinci yang melayani 2 daerah yaitu Kabupaten Kerinci dan Kota Sungai penuh.

\section{- Sarana Prasarana}

Unsur sarana prasarana merupakan fasilitas yang diperlukan oleh suatu organisasi untuk menjalankan semua kegiatan yang telah direncanakan untuk mencapai tujuan organisasi (Muninjaya, 2004). Sarana dalam pelaksanaan program jaminan kesehatan nasional adalah semua sarana prasarana yang mendukung kelancaran dalam pelaksanaan program. ${ }^{11}$

Berdasarkan hasil penelitian diketahui masih adanya kekurangan pada sarana prasarana terutama pada ruang perawatan kelas II dan III. Peneliti menemukan masih banyaknya masalah seperti kurangnya kipas angin, ventilasi udara dan tirai pembatas hal ini menyebabkan panasnya ruangan pada siang hari dan tidak adanya tirai pembatas membuat pasien merasa risih jika sedang dilakukan tindakan oleh dokter ataupun perawat .

Penelitian yang dilakukan oleh Khariza (2015), tentang Studi Deskriptif tentang Faktor - Faktor yang Dapat Mempengaruhi Keberhasilan Implementasi Program Jaminan Ksehatan Nasional di Rumah Sakit Jiwa Menur Surabaya didapatkan fasitas pendukung fisik belum cukup memadai, hal tersebut terlihat dari kurangnya fasilitas pendukung fisik diruang rawat inap kelas 1, 2. 3 yaitu berupa ketersediaan tempat tidur yang belum memadai. ${ }^{7}$ Penelitian yang dilakukan oleh Sidin et al (2015) tentang Kepuasan Peserta JKN Terhadap Kualitas Pelayanan Kesehatan Menggunakan Indikator HCAHPS di Instalasi Rawat Inap RS Stela Mari Makasar 2015 didapatkan sarana dan prasarana yang tidak memadai kursi penjaga 
pasien yang tidak ada, tempat tidur pasien yang udah tua, kipas angin yang sudah tidak layak, serta kendala lainnya seperti kenyamanan pasien yang merasa terganggu dengan kebisingan dari luar kamar perawatan sehingga pasien tidak dapat beristirahat dengan tenang. ${ }^{12}$

Analisis yang telah dilakukan dari hasil temuan tentang masih adanya kekurangan sarana prasarana pada ruang perawatan perlu melakukan penambahan dan perbaikan sarana prasarana ini guna untuk lebih meningkatkan kenyamanan pasien selama dirawat sehingga nilai kepuasan terhadap pelayanan Rumah Sakit X Kabupaten Kerinci juga meningkat lebih baik.

\section{Kompunen Proses}

\section{- Bukti Fisik}

Mutu jasa pelayanan kesehatan juga dapat dirasakan secara langsung oleh para penggunanya yaitu pasien dengan menyediakan fasilitas fisik dan perlengkapan yang memadai. Dalam hal ini, pengguna jasa menggunakan indranya untuk menilai kualitas jasa pelayanan kesehatan yang diterimanya seperti ruang penerimaan pasien yang bersih, nyaman, lantai yang berkeramik, peralatan kator yang lengkap, seragam staf yang rapi, menarik dan bersih (Muninjaya, 2004). ${ }^{11}$

Berdasarkan hasil penelitian terhadap dimensi mutu bukti fisik didapatkan masih ada informan yang kurang puas dengan pelayanan rumah sakit dari segi failitas dikatahui bahwa masih adanya fasilitas ruangan yang kurang yaitu tidak ada kipas angin dan yang sudah ada kipas angin juga tidak dapat dipakai lagi karena kondisinya sudah rusak sehingga ruangan perawatan pasien pada siang hari terasa panas, dilihat dari segi ventilasi udara masih kurang. Fasilitas lainnya yang kurang seperti tidak adanya tirai pembatas antara tempat tidur pasien sehingga pasien merasa kurang nyaman ketika mendapatkan perawatan dari dokter ataupun perawat. Selain itu tidak adanya aturan bagi tamu yang membesuk pasien sehingga banyaknya orang yang masuk keruangan sehingga bisa mengganggu pasien lainnya dan kebersihan ruangan juga menjadi tidak terjaga.

Hal tersebut sejalan dengan penelitian yang dilakukan oleh Zamil et al (2012), menyatakan bahwa lingkungan rumah sakit merupakan salah satu faktor yang mempengaruhi tingkat kepuasan pasien. ${ }^{13}$ Penelitian Musdalifah et al (2015) tentang analisis perbedaan kepuasan pasien JKN dan umum di RSUD Bantaeng tahun 2015 di dapat variabel bukti fisik rumah sakit masih mendapatkan jawaban buruk, hal tersebut dikarenakan pada rungan perawatan khususnya pada ruangan perawatan kelas III tidak memiliki sekat atau tirai pemisah sehingga membuat pasien terganggu dengan pasien, keluarga atau pengunjung pasien lain. ${ }^{14}$

Fasilitas fisik dan perlengkapan yang memadai merupakan mutu jasa pelayanan kesehatan yang dapat dirasakan secara langsung oleh para penggunanya. Para penyedia layanan kesehatan akan mampu bekerja secara optimal sesuai dengan keterampilan masing-masing jika didukung dengan perlengkapan yang memadai, pasien juga dapat cepat sebuh dengan adanya kenyamanan yang dirasakan didalam ruang rawatan seperti kebersihan terjaga, tidak panas dan pengap. Ruangan yang menarik dan bersih juga mampu meningkatkan kepuasan bagi pengguna jasa tersebut.

\section{- Kehandalan}

Kemampuan untuk memberikan pelayanan kesehatan dengan tepat waktu dan akurat sesuai dengan yang ditawarkan. Untuk meningkatkan Reliability di bidang pelayanan kesehatan, pihak manajemen puncak perlu membangun budaya kerja bermutu yaitu budaya tidak ada kesalahan atau corporate culture of no mistake yang ditetapkan mulai dari pimpinan puncak sampai ke front line staff (yang langsung berhubungan dengan pasien) dan perlu diterapkan terus menerus sesuai dengan teknologi dan ekspektasi pasien (Muninjaya, 2011). ${ }^{11}$

Berdasarkan hasil penelitian yang di lakukan pada dimensi mutu kehandalan didapatkan semua responden merasa puas dan dikatahui bahwa waktu tunggu untuk mendapatkan tempat tidur di Rumah Sakit X Kabupaten Kerinci membutuhkan waktu 1 hari, hal ini sesuai dengan indikatator rumah sakit BOR sebesar $85 \%$, angka BOR menunjukkan tingkat pemamfaatan tempat tidur yang cukup tinggi. Sehingga perlu pengembangan rumah sakit atau penambahan tempat tidur. Paramedis diruang rawat inap sudah cukup handal dalam menyelesaikan 
masalah yang dihadapi pasien, hal ini terlihat tidak ada kendala dalam melakukan tindakan perawatan.

Penelitian yang dilakukan Hidayati et al (2017), tentang Konsep Kualitas Pelayanan Kesehatan berdasar atas Ekspektasi Peserta Jaminan Kesehatan Nasional. Dalam penelitian ini pasien mengharapkan waktu tunggu yang tidak lama dalam mendapatkan pelayanan. $^{15}$ Dimensi ini menyangkut care service contohnya meliputi petugas yang menerima pasien sesuai dengan prosedur, waktu tunggu untuk pelayanan cepat, petugas melayani pasien dengan tepat, dan petugas melakukan pemeriksaan dengan cepat dan tepat.

Dimensi mutu kehandalan dari petugas ruangan Rumah Sakit X Kabupaten Kerinci sudah memuaskan responden, hal tersebut terlihat dari seluruh responden merasa puas dengan pelayanan dari segi dimensi mutu kehandalan. Kehandalan dalam arti memberikan pelayanan yang dijanjikan dengan segera, akurat dan memuaskan pelanggan. Petugas ruangan dalam memberikan pelayanan selalu tepat waktu dan perawatan selesai sesuai dengan yang diharapkan responden. Untuk meningkatkan pelayanan kesehatan khususnya dimensi mutu kehandalan. maka pihak manajemen puncak dapat membangun budaya kerja bermutu yaitu budaya tidak ada kesalahan atau corporate culture of no mistake yang ditetapkan mulai dari pimpinan puncak sampai ke front line staff (yang langsung berhubungan dengan pasien).

\section{- Daya Tanggap}

Dimensi ini dimasukkan ke dalam kemampuan petugas kesehatan menolong pelanggan dari kesiapannya melayani sesuai prosedur dan bisa memenuhi harapan pasien. Pelayanan kesehatan yang responsif terhadap kebutuhan pasiennya kebanyakan ditentukan oleh sikap para front line staff. Mereka secara langsung berhubungan dengan para pengguna jasa dan keluarganya, baik melalui tatap muka, komunikasi non verbal langsung atau melalui telepon (Muninjaya, 2011). ${ }^{11}$

Berdasarkan hasil penelitian dikatahui dimensi mutu daya tanggap sudah berjalan dengan baik, hal ini sesuai dengan hasil wawancara dengan informan dan didapatkan semua informan merasa puas dengan daya tanggap yang diberikan oleh petugas dirumah sakit karena petugas diruang rawat inap Rumah Sakit X Kabupaten Kerinci cepat tanggap dalam membantu kebutuhan informan dalam segala hal yang berkaitan dengan perawatan informan. Informasi yang disampaikan petugas dapat dimengerti oleh informan dan perawat juga datang dengan cepat jika dibutuhkan tenaganya oleh informan.

Penelitian ini sejalan dengan penelitian yang dilakukan oleh Musdalifah et al (2016), berdasarkan item pernyataan dalam variabel daya tanggap keseluruhan pernyataan mendapatkan persepsi yang baik. Hal ini didukung dari beberapa responden yang menyatakan bahwa tidak terdapat kesulitan yang dihadapi mulai dari pertama menjalani perawatan sampai proses meninggalkan rumah sakit yang tidak lain berkat kesigapan dan bantuan petugas rumah sakit yang cepat dan sangat membentu. Variabel daya tanggap petugas kesehatan sangat berpengaruh terhadap persepsi pasien. ${ }^{14}$

Daya tangga petugas kesehatan sangat berpengaruh terhadap mutu pelayanan kesehatan dan kepuasan pasien. Hal ini dilihat dari semua informan merasa puas pada petugas yang membantu kebutuhan pasien dalam segala hal yang berkaitan dengan perawatan pasien. Informasi yang disampaikan petugas dapat dimengerti oleh pasien, perawat juga datang dengan cepat jika dibutuhkan tenaganya, pasien tidak mendapatkan kesulitan dalam melakukan proses perawataan dirumah sakit.

\section{- Jaminan}

Kriteria ini berhubungan dengan pengetahuan, kesopanan dan sifat petugas yang dapat dipercaya oleh pasien. Pemenuhan terhadap kriteria pelayanan ini akan mengakibatkan pengguna jasa merasa terbebas dari resiko. Berdasarkan riset, dimensi ini meliputi faktor keramahan, kompetensi, kredibilitas dan keamanan. Variabel ini perlu dikembangkan oleh pihak manajemen institusi pelayanan kesehatan dengan melakukan investasi, tidak saja dalam bentuk uang melainkan keteladanan manajemen puncak, perubahan sikap dan kepribadian staf yang positif, dan perbaikan sistem remunerasinya. ${ }^{11}$

Berdasarkan hasil penelitian, diketahui bahwa petugas diruang rawat inap Rumah Sakit X Kabupaten 
Kerinci melakukan tindakan perawatan yang baik dan sesuai prosedur yang ditetapkan. Setiap pertanyaan yang diajukan oleh pasien mengenai penyakitnya dijawab dengan sopan. Hal ini meningkatkan kepercayaan pasien pada tenaga kesehatan diruang rawat inap Rumah Sakit X Kabupaten Kerinci.

Penelitian yang dilakukan oleh Amna (2012) secara umum tingkat pelaksanaan pelayanan yang dijanjikan pihak manajemen rumah sakit kepada pasien sudah dilaksanakan oleh petugas kesehatan, tetapi karena masih adanya petugas yang tidak ada ditempat pada jam kerja dengan alasan apapun, perlu untuk dilakukan penertiban kembali. Sedangkan untuk petugas yang kurang mampu menjawab pertanyaan pasien dengan jawaban yang meyakinkan, perlu adanya peningkatan kemampuan sumber daya manusia dengan cara mengirimkan ke pelatihan, mengirimkan tugas belajar ataupun supaya petugas tersebut sering membaca buku sehingga meningkatkan pengetahuannya. ${ }^{16}$

Item mutu jaminan yang peneliti lihat disini yaitu pengetahuan dan kemampuan para dokter dalam mendiagnosa suatu penyakit, jaminan keamanan dalam melakukan pelayanan dan kepercayaan responden terhadap pelayanan yang dilakukan petugas kesehatan diruang rawat inap. Peneliti mendapatkan hasil yang baik dari responden untuk dimensi mutu ini, perawat menjelakan dengan bahasa yang mudah dimengerti, perawat bisa menjelakan dengan jelas kepada responden mengenai diagnosa penyakit yang responden tanyakan, sehingga pasien maupun keluarga pasien merasa puas dengan jawaban yang diberikan.

\section{- Kepedulian}

Kriteria ini terkait dengan rasa kepedulian dan perhatian khusus staf kepada setiap pengguna jasa, memahami kebutuhan mereka dan memberikan kemudahan untuk dihubungi setiap saat jika para pengguna jasa ingin memperoleh bantuannya. ${ }^{11}$

Berdasarkan hasil penelitian dikatahui bahwa seluruh responden merasa puas dengan dimensi mutu kepedulian karena tenaga kesehatan di ruang rawat pasien. Perawat dan dokter juga menanyakan kabar dari pasien dan bagaimana kemajuan kesehatannya selama pasien tersebut dirawat di Rumah Sakit X.
Penelitian yang dilakukan Sidin et al (2015), tentang kepuasan peserta JKN terhadap kualitas pelayanan kesehatan menggunakan indikator HCAHPS di instalasi rawat inap RS Stela Maris Makasar Indonesia mengatakan komunikasi dokter sangat mempengaruhi kepuasan pasien dalam pelayanan RS, namun masih ada sebagian besar dokter yang menjadi dokter penanggung jawab pasien tidak memperkenalkan dirinya kepada pasien sehingga pasien merasa canggung saat bertemu kembali dengan dokter, penyebabnya terdapat pasien yang diperlakukaan tidak sopan dan hormat dikarenakan masih ada sebagian dokter yang menganggap pasien hanya perlu mendengar dan menerima apa yang dikatakan dokter. ${ }^{12}$

Kepuasan pelanggan merupakan tingkat perasaan seseorang setelah membandingkan kinerja atau hasil pelayanan yang dirasakannya dengan harapan pelanggan sebelum mendapatkan pelayanan. Pelayanan kesehatan memiliki keunikan tersendiri, ada banyak aspek yang dapat mengukur kepuasan pasien tapi hanya sedikit yang dapat menggambarkan kepuasan pasien, salah satunya dimensi mutu kepedulian petugas rumah sakit yang sangat mempengaruhi kepuasan para pengguna jasa pelayanan kesehatan dengan memahami kebutuhan mereka dan memberikan kemudahan untuk mendapatkan informasi saat mereka ingin memperoleh bantuannya. Komunikasi petugas rumah sakit dengan pasien memberikan dampak yang besar bagi pasien khususnya dalam hal kenyamanan dan kepuasan pasien karena mampu menyelesaikan masalah kesehatan pasien.

\section{- Pengajuan Klaim}

Penelitian Malonda et al yang berjudul Analisis pengajuan klaim Badan Penyelenggara Jaminan Sosial (BPJS) Kesehatan di RSUD Dr. Sam Ratulangi Tondano 2015 yang menyatakan sebagian besar status rekam medis yang berhubungan dengan dokumen klaim tidak diisi dengan lengkap yang meliputi identitas pasien: identitas umum (nama, umur, tempat tanggal lahir, alamat, nomor handphone/telepon, pendidikan, pekerjaan, status perkawinan, penanggungjawab pembayaran), identitas khusus (nomor rekam medis, nomor surat eligibilitas pasien (SEP), tanggal masuk, tanggal keluar. Petugas 
rekam medis juga sering lupa melampirkan rujukan pasien dan tidak menuliskan data kepesertaan, begitu juga pengembalian rekam medis dan penyerahan dokumen klaim tidak tepat waktu. ${ }^{17}$

Berdasarkan hasil penelitian terlihat masih adanya keterlambatan pengajuan klaim dari rumah sakit. Hal ini disebabkan karena pihak managemen Rumah Sakit X Kabupaten Kerinci tidak melakukan supervisi secara berkala terhadap pelaksanaan proses pengajuan klaim, sehingga menyebabkan menumpuknya berkas klaim untuk di grouping dan koding. Bagian koding harus entry data secara manual karena rumah sakit belum menggunakan sistim SIMRS karena peralatan yang kurang mendukung. Solusinya perlu melakukan pengawasan untuk memastikan semua proses/tahap pengajuan berjalan sesuai dengan petunjuk teknis dan SOP, pengawasan dilakukan secara berkala dan juga perlu melakukan pengadaan barang untuk SIMRS sehingga kerja menjadi lebih optimal.

Penelitian yang dilakukan Noviatri dan Sugeng (2016) tentang analisis faktor penyebab keterlambatan penyerahan klaim BPJS di RS Panti Nugroho menyatakan machines yang digunakan petugas terkendala pada server dari BPJS yang eror, untuk SIMRS belum digunakan karena masih rawan terputus sehingga rumah sakit menggunakan system manual. ${ }^{18}$

\section{Kompunen Output}

Keluaran (Output) adalah kumpulan bagian atau elemen yang dihasilkan dari berfungsinya proses dalam sistem. Keluaran (Output) merupakan hasil langsung dari suatu sistem, proses yang berjalan dengan baik akan mempengaruhi mutu dari suatu produk. Mutu pelayanan kesehatan merupakan kesempurnaan dari suatu produk dalam pelayanan kesehatan yang dapat memuaskan setiap pengguna jasa. Pelayanan yang bermutu merupakan penyelanggaraan pelayanan yang sesuai dengan prosedur dan standar kode etik profesi yang telah ditetapkan, dengan menyesuaikan potensi dari sumber daya yang tersedia secara aman dan memuaskan yang dilakukan secara wajar, efisien dan efektif dengan memperhatikan keterbatasan dan kemampuan pemerintah dan masyarakat atau konsumen. ${ }^{5}$
Berdasarkan mutu pelayanan kesehatan yang peneliti temukan diruang rawat inap Rumah Sakit $X$ Kabupaten Kerinci terlihat bahwa mutu pelayanan kesehatan sudah cukup memuaskan, hal ini terlihat dari hasil wawancara peneliti terhadap pasien, didapatkan seluruh pasien merasa puas dengan pelayanan rumah sakit dari dimensi mutu kehandalan, daya tanggap, jaminan dan kepedulian, hal ini dikarenakan tenaga kesehatan sudah menjalankan tugasnya sesuai dengan prosedur pelayanan yang dikeluarkan oleh rumah sakit, juga sudah mampu menjawab kebutuhan pasien. Pada dimensi mutu bukti fisik sebagian pasien merasa kurang puas, karena fasilitas yang ada didalam ruang rawat inap kurang.

Hasil penelitian yang dilakukan oleh Muliana et al (2015) di RSUD Kota Makasar menunjukkan hasil bahwa terdapat hubungan yang signifikan antara dimensi Reability, Tangible, Emphaty, Responsiveness dan Amenity dengan kepuasan pasien BPJS diunit rawat inap RSUD Kota Makasar. ${ }^{19}$ Penelitian ini juga memperlihatkan bahwa tidak ditemukan adanya hubungan yang signifikan antara dimensi Ansurance, jumlah personal dan ketersediaan obat dengan kepuasan pasien BPJS diunit rawat inap RSUD Kota Makasar. Hasil penelitian Irwandy (2016) yang di kota Makasar menunjukkan bahwa tingkat kepuasan pasien JKN terhadap pelayanan rumah akit berada berada pada katagori baik yakni $87,7 \%$ dimana angka tersebut telah diatas target yang telah ditetapkan yakni 85\%. Dimensi pengukuran kehandalan 91,6\%, jaminan kepastian $88,5 \%$, keadaan fisik $88,5 \%$, pemahaman $89 \%$ dan tanggung jawab $89.7 \%$, hal tersebut menunjukkan adanya pengaruh mutu pelayanan kesehatan terhadap kepuasan pasien. ${ }^{20}$

\section{SIMPULAN}

Dimensi mutu kehandalan, daya tanggap, jaminan dan kepedulian sudah bisa menjawab kebutuhan responden dan yang masih mendapatkan keluhan pasien dari dimensi mutu bukti fisik.

\section{UCAPAN TERIMAKASIH}

Terima kasih kepada semua pihak yang telah membantu dalam penyelesaian dan penyempurnaan penelitian ini, Khususnya kepada direktur Rumah Sakit 
$X$ Kabupaten Kerinci, berserta staf yang telah memfasilitasi dalam melakukan penelitian.

\section{DAFTAR PUSTAKA}

1. Undang-Undang Republik Indonesia Nomor 24 Tahun 2011. Badan Penyelenggaraan Jaminan Nasional. 25 November 2011. Jakarta: Lembar Negara Republik Indonesia Tahun 2011 Nomor 116; 2011.

2. BPJS Kesehatan RI. Rekapitulasi kepesertaan BPJS kesehatan sampai dengan tanggal 11 maret 2016. BPJS Kesehatan RI.

3. Moleong LJ. Metodologi penelitian kualitatif. Edisi ke-36. Bandung: Remaja Rosdakarya; 2017.

4. Sugiyono. Statistika untuk penelitian. Edisi ke-29. Bandung: Alfabeta; 2017.

5. Azwar A. Pengantar administrasi kesehatan. Edisi III. Jakarta: Binarupa Aksara; 2010.

6. Undang-Undang Republik Indonesia Nomor 40 Tahun 2004. Sistem Jaminan Sosial Nasional. 19 Oktober 2004. Jakarta. Lembaga Negara Republik Indonesia Tahun 2004 Nomor 150; 2004.

7. Khariza HA. Program jaminan kesehatan nasional: studi deskriptif tentang faktor-faktor yang dapat mempengaruhi keberhasilan implementasi program jaminan kesehatan nasional di rumah sakit jiwa Menur Surabaya. Jurnal Kebijakan dan Managemen Publik. 2015;3(1):230-341.

8. Ernawati CT, Azkha N. Studi implementasi BLUD di UPTD balai kesehatan indera masyarakat provinsi Sumatera Barat tahun 2016. Jurnal Kesehatan Masyarakat Andalas. 2018;12(2):13-22.

9. Hasibuan MPS. Managemen sumber daya manusia. Jakarta: Bumi Aksara; 2016.

10. Saputra M, Marlinae L, Rahman F, Rosadi D. Program jaminan kesehatan nasional dari aspek sumber daya Manusia Pelaksanaan Pelayanan Kesehatan. Jurnal Kesehatan Masyarakat. 2015;11(1):32-42.

11. Muninjaya AAG. Managemen kesehatan. Edisi keII. Jakarta: EGC; 2004.

12. Sidin Al, Noor NB, Adayanti N. Kepuasan pasien JKN terhadap kualitas pelayanan kesehatan menggunakan indikator HCAHPS di instalasi rawat inap RS Stella Maria Makasar. Jurnal Kebijakan Kesehatan Indonesia. 2015;5(1):14-22.

13. Zamil M, Ahmad. The impact of health service qualiry on patients' satifaction over private and public hospital in Jordan [Tesis]. Saudi Arabia: Faculty Of A Administrative Science King Saudi University; 2012.

14. Musdalifah, Irwandy, Maidi A. Analisis perbedaan kepuasan pasien JKN dan umum di RSUD Bantaeng. Jurnal Kebijakan Kesehatan Indonesia. 2016;5(1):33-9.

15. Hidayati I, Sakarwana N, Sanjaya DK, Setiawati, EP. Konsep kualitas pelayanan kesehatan berdasarkan atas ekspektasi peserta jaminan kesehatan nasional. MKB.2017;49(2):102-9.

16. Amna Z. Faktor-faktor yang berhubungan dengan mutu pelayanan kesehatan pada poli KIA RSUD Kota Subang tahun 2012. Electronic Journal in StiKes Ubudiyah. 2012 (diunduh 7 Januari 2019). Tersedia dari: https://www.goole.com/url?sa= t\&source=web\&rct=i\&url

17. Malonda TD, Rattu AJM, Soleman T. Analisis pengajuan klaim badan penyelenggara jaminan sosial (BPJS) kesehatan di RSUD Dr. Sam Ratulangi Tondano. Electronic Journal in Unsrat. 2015 (diunduh 14 Juni 2018). Tersedia dari: http://ejournal.unsrat.ac.id/index.php/jikmu/article/vi $\underline{\text { ew/7852 }}$

18. Noviatri LW, Sugeng. Analisis faktor penyebab keterlambatan penyerahan klaim BPJS di rumah sakit Panti Nugroho. Jurnal Kesehatan Vokasional. 2016;1(1):22-6.

19. Muliana, Nuhayani, Balqis. Evaluasi terhadap implementasi kebijakan tarif pelayanan kesehatan (tariff ina-cbgs) di rumah sakit umum daerah kota makasar. Electronic Journal in UNHAS Repository System. 2015 (diunduh 20 Juli 2018). Tersedia dari: $\quad$ http://repository.unhas.ac.id/handle/ $\underline{123456789 / 13148}$

20. Irwandy. Kajian literatur: evaluasi pelaksanaan program jaminan kesehatan nasional di Indonesia. Jurnal Kebijakan Kesehatan Indonesia 2016;5(3): 110-4. 